\title{
Feeding of European pilchard (Sardina pilchardus) in the northwestern Mediterranean: from late larvae to adults
}

\author{
David Costalago $^{1,2}$, Isabel Palomera ${ }^{1}$ \\ ${ }^{1}$ Institut de Ciències del Mar (ICM-CSIC), Passeig Marítim de la Barceloneta 37-49, 08003 Barcelona, Spain. \\ E-mail: nauplius97@gmail.com \\ ${ }^{2}$ Present address: Department of Zoology, Nelson Mandela Metropolitan University, P.O. Box 77000, Port Elizabeth, \\ 6031 South Africa
}

\begin{abstract}
Summary: We assessed the relative importance of different prey types of the European pilchard (European sardine) from the late larval to the adult stage. Two different methodologies for analysing stomach contents were used to describe the trophic dynamics of sardine and the relationship of sardine feeding behaviour with the ontogenetic development of body structures used for feeding, such as gill rakers and pyloric caeca. This information is essential to accurately depict the use of the planktonic resources in the area by sardine and to discuss the extent to which the sardine population could be affected by environmental changes in the Mediterranean Sea. We showed that cladocerans in summer and diatoms in winter were numerically the most important prey types for both juveniles and adults. However, decapod larvae were the most important prey during all seasons in terms of carbon content. Accordingly, differences in methodology should be considered in the analysis of sardine diets. An analysis of the composition of the plankton showed that small copepods were strongly selected by sardines at all ages and in both seasons. We also observed that the pyloric caeca began to grow when the sardines were approximately $4-5 \mathrm{~cm}$ standard length (SL) and ended their development when the sardines reached approximately $8 \mathrm{~cm}$ SL, whereas the gill rakers appeared to be completely functional when the sardines reached $7 \mathrm{~cm} \mathrm{SL}$. Therefore, filter feeding of small particles could be performed with total efficacy beginning at 7-8 cm SL. In view of the energetic advantage of filter feeding in a well-adapted filter-feeding species such as sardine, the prospective limited availability of small particles hypothesized by certain authors for the Mediterranean could have negative consequences for sardine. This study demonstrates that sardine populations, given their extremely high dependence on the lower marine trophic levels, could be strongly affected by alterations in the environment and in the planktonic community.
\end{abstract}

Keywords: Sardina pilchardus; northwestern Mediterranean; ontogeny; trophic ecology; small pelagic fish.

Alimentación de la sardina europea (Sardina pilchardus) en el Mediterráneo noroccidental: de post-larva a adulto

Resumen: Analizamos la importancia relativa de los diferentes tipos de presas de la sardina europea, desde post-larvas hasta adultos. Se usaron dos métodos diferentes de análisis de los contenidos estomacales para describir la dinámica trófica de la sardina y la relación de su comportamiento alimenticio con el desarrollo ontogénico de las estructuras corporales que usa en el proceso alimenticio, como las brianquispinas y los ciegos pilóricos. Esta información es esencial para obtener una imagen precisa de los recursos planctónicos de los que dispone la sardina en el área y para discutir de qué forma la población de sardina podría verse afectada por cambios medioambientales en el mar Mediterráneo. Mostramos que los cladóceros, en verano, y las diatomeas, en invierno, fueron los tipos de presas más importantes tanto para juveniles como para adultos. Sin embargo, las larvas de decápodos fueron las presas más importantes durante todas las estaciones en términos de contenido en carbono. En consecuencia, las diferencias metodológicas deberían ser tenidas en cuenta en el análisis de dietas. Con el análisis de la composición del plancton se mostró que los copépodos pequeños eran fuertemente seleccionados por sardinas de todas las edades y en ambas estaciones. También observamos que los ciegos pilóricos empezaron a crecer cuando las sardinas alcanzaban aproximadamente $4-5 \mathrm{~cm}$ de longitud estándar (LE), y su desarrollo acababa cuando las sardinas alcanzaban aproximadamente $8 \mathrm{~cm} \mathrm{LE}$, mientras que las branquispinas parecieron ser completamente funcionales cuando las sardinas alcanzaron los $7 \mathrm{~cm}$ LE. Por tanto, la alimentación por filtración de pequeñas partículas podría ser llevada a cabo con total eficacia cuando las sardinas tienen 7-8 cm LE. En vista de la ventaja energética de la alimentación filtradora en especies bien adaptadas a la filtración como la sardina, la potencialmente limitada disponibilidad de pequeñas partículas que ciertos autores han hipotetizado para el Mediterráneo podría tener consecuencias negativas para la sardina. Este estudio demuestra que las poblaciones de sardina, dada su extremadamente alta dependencia de los niveles tróficos marinos inferiores, podrían verse fuertemente afectadas por alteraciones en el medio y en la comunidad planctónica.

Palabras clave: Sardina pilchardus; Mediterráneo noroccidental; ontogenia; ecología trófica; peces pelágicos pequeños.

Citation/Como citar este artículo: Costalago D., Palomera I. 2014. Feeding of European pilchard (Sardina pilchardus) in the northwestern Mediterranean: from late larvae to adults. Sci. Mar. 78(1): 41-54 doi: http://dx.doi.org/10.3989/ scimar.03898.06D

Editor: E. Massutí. 
Received: May 28, 2013. Accepted: December 13, 2013. Published: March 6, 2014

Copyright: (C) 2014 CSIC. This is an open-access article distributed under the Creative Commons Attribution-Non Commercial Lisence (by-nc) Spain 3.0.

\section{INTRODUCTION}

Currently, most marine fish ecologists consider that the dietary habits of a fish species may depend upon both the availability of prey (Frederiksen et al. 2006) and the anatomy of the fish (Gerking 1994, Wainwright et al. 1995). However, the mechanisms that fishes employ for feeding are diverse. In clupeids, two different feeding methods are generally assumed, namely, particulate (selective) and filter (non-selective) feeding (James 1986). The switch from one feeding mode to the other depends primarily on the concentration of food (Bulgakova 1996) and can also shift in response to changes in the presence and abundance of particular prey items (van der Lingen 1994) if the ontogenetic development of the individuals so permits (Turingan et al. 2005). Therefore, changes in the lowest trophic level of the ecosystem can have drastic consequences for fish recruitment (Cushing 1990, Beaugrand et al. 2003), particularly in small pelagic fish species, whose prey is exclusively planktonic (Durbin 1979, Blaxter and Hunter 1982, Checkley et al. 2009).

The European sardine or pilchard, Sardina pilchardus, is a rapidly growing and short-lived small pelagic fish species. It is one of the most important fish resources throughout its range in the northeastern Atlantic, from the North Sea to the Senegalese coast, including the Mediterranean and the Black Seas. Studies of its feeding dynamics have been conducted on the Atlantic coast of Spain, where the diets of juvenile and adult sardine have been found to consist entirely of plankton (Bode et al. 2004, Garrido et al. 2007, 2008) and where adults are able to perform both filter and particulate feeding. Due to this difference between stages, the adults show a greater fraction of phytoplankton in their stomachs than the juveniles do. In contrast, it has been shown that sardine larvae in the same region generally feed on copepods (Conway et al. 1994, Munuera and González-Quirós 2006).

Few previous studies have investigated the feeding behaviour of sardine in the Mediterranean Sea (Nikolioudakis et al. 2011, 2012, Borme et al. 2013). Information on this topic is particularly scarce for the western Mediterranean. Two non-recent studies (Massuti and Oliver 1948, Lee 1961) considered sardine primarily zooplanktivorous, especially after reaching the juvenile stage, and only two other more recent studies, by Rasoanarivo et al. (1991) and Morote et al. (2010), have considered sardine feeding behaviour in the Gulf of Lions and in the Catalan Sea, respectively. Both of these more recent studies focused strictly on larvae smaller than $15 \mathrm{~mm}$ standard length (SL). Additionally, a study of all ontogenetic stages from larvae to adults by Costalago et al. (2012) investigated the diet of sardine in the Gulf of Lions using stable isotopes.

Despite the ecological and commercial importance of sardine in the northwestern Mediterranean (Palom- era et al. 2007), information on the trophic ecology of this species in the area remains scarce. Therefore, the main goal of this study was to fill that gap in current knowledge and to contribute to an improved understanding of the functioning of the pelagic ecosystem in the northwestern Mediterranean. Ecological models based on trophic web interactions and capable of quantitatively describing the structure and function of exploited marine ecosystems (e.g. Ecopath/Ecosim, see Banaru et al. 2012, Coll et al. 2006) have described sardine in the northwestern Mediterranean as a key species in the trophic web but, with the exception of data from Lee (1961) used in Banaru et al. (2012), these models have used data on the diet of sardine from regions other than the northwestern Mediterranean, such as the eastern Mediterranean (Demirhindi 1961) and the Atlantic coast of Spain (Bode et al. 2004, Garrido et al. 2008). Moreover, detailing the ontogenetic fractions of key species included in the models (e.g. sardine) from an ecological point of view is one of the major tasks that remain to be carried out.

The area of study, the Gulf of Lions in the northwestern Mediterranean, is highly productive compared with the generally oligotrophic Mediterranean Sea (Bakun and Agostini 2001), owing primarily to water discharges from the Rhône River and the dominant northern winds that distribute nutrients and particulate organic matter along the entire continental shelf (Estrada 1996, Salat 1996) and can even cause occasional small upwelling events (Forget and André 2007). Additionally, this area is a very important nursery habitat for both European anchovy (Engraulis encrasicolus) and sardine (Giannoulaki et al. 2011, 2013). Accordingly, the Gulf of Lions has an important fishery for small pelagic fish, particularly anchovy and sardine (Lleonart and Maynou 2003, Palomera et al. 2007) that is linked directly to the environmental features described above (Lloret et al. 2004).

However, according to the General Fisheries Commission for the Mediterranean (GFCM; see GFCM 2012), the sardine in the Gulf of Lions has experienced a decrease during the last decade in both tonnes of catches and biomass, and its population has reached a critical state. In addition, the mean size-at-age of these fish has also decreased in recent years (Voulgaridou and Stergiou 2003, D. Roos, personal communication for data from 2005 on), with potential consequences for the viability of the population. To maintain this commercial fishing activity on this population without jeopardizing the future of the stock, management must be based on comprehensive studies of the ecology of the exploited species and the environment. Accordingly, environmental and trophodynamic drivers must receive thorough study because fish biomass trends, and therefore all subsequent anthropogenic activities (such as fisheries), depend strongly on these drivers (Fu et al. 2012). 


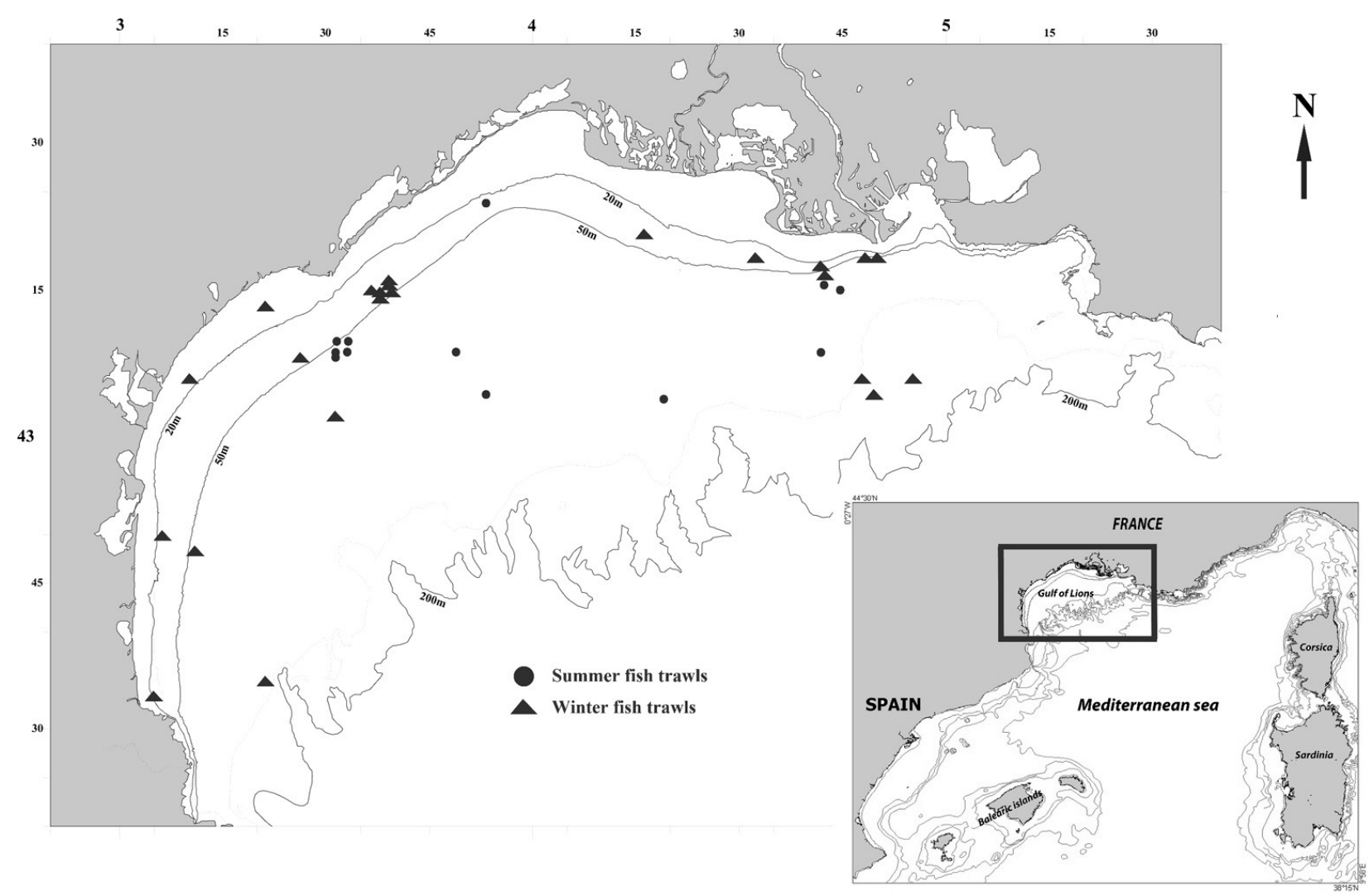

Fig. 1. - Study area (Gulf of Lions, NW Mediterranean), indicating fish and plankton sampling locations.

In this study, we assessed the relative importance of different prey types of sardine using two methods for analysing stomach contents. The first method is based on the numerical abundance of each prey item in the stomachs and the second estimates the carbon content of the prey items and hence indicates the actual importance that each prey type can have in the carbon flux from one trophic level to the next. Although some recent and very extensive works, such as the one by van der Lingen et al. (2009), have used data obtained mainly through the numerical analysis of preys in the stomachs of small pelagic fish, we consider that a comparison of the two methods is still essential to determine whether one of them describes the diet of these species more accurately.

Additionally, the current study represents the first attempt to identify a pattern in the daily ration and consumption rates. Owing, presumably, to the practical difficulties of conducting this type of observation at sea, there are, to our knowledge, no previous field studies of the daily feeding activity of sardine in the western Mediterranean. Therefore, although our results on this topic are based on only a single 24 -h cycle, we consider that they are important and should be reported.

The final aim of this study was to describe the trophic dynamics of sardine from late larvae to adults through the analysis of stomach contents and to show how feeding behaviour is related to the ontogenetic development of body structures, such as gill rakers and pyloric caeca, used in feeding. This information is essential to obtain an accurate picture of the ways in which sardine utilizes the available planktonic re- sources in the area and to discuss the ways in which prospective changes in the plankton community could affect sardine populations in the Mediterranean Sea.

\section{MATERIALS AND METHODS}

\section{Study area and sample collection}

This study was conducted in the Gulf of Lions (Fig. 1 ), one of the most productive areas of the northwestern Mediterranean (Salat 1996). In terms of fish biomass, it is also one of the most important areas in the Mediterranean for small pelagic fish species (Barangé et al. 2009).

Two cruises were performed during two different seasons (summer and winter) on board the N/O L'Europe (Ifremer, France). The summer cruise (PELMED07) was conducted in July-August 2007 and the winter cruise (JUVALION09) was in January 2009.

Plankton samples were collected during each season (16 plankton sampling stations in summer and 13 in winter). To obtain the $200-$ to $3000-\mu \mathrm{m}$ mesozooplankton fraction, a standard WP2 net with a mesh size of $200 \mu \mathrm{m}$ was used, with sieving through a 3000- $\mu \mathrm{m}$ plankton mesh. Similarly, to obtain the 53- to 200 $-\mu \mathrm{m}$ microplankton fraction, a scaled-down WP2 net with a mesh size of $53 \mu \mathrm{m}$ was used, and the samples were sieved through a $200-\mu \mathrm{m}$ plankton mesh. All plankton samples were split with a Motoda plankton splitter (Motoda 1959). One-half of each sample was preserved in buffered $4 \%$ formaldehyde-seawater solution for subsequent qualitative analysis of plankton 
Table 1. - Mean standard lengths (SL) and SL ranges of sardines caught during the summer 2007 and winter 2009 cruises. N, number of individuals analysed.

\begin{tabular}{lcccc}
\hline & $\begin{array}{c}\text { Late larva } \\
\text { Winter }\end{array}$ & Summer & Juveniles & Adults \\
& Winter & 272 & Summer & 367 \\
$\mathrm{~N}$ & 334 & 223 & 9.52 & 13.05 \\
Mean SL $(\mathrm{cm})$ & 3.09 & 7.73 & $7.8-10.9$ & 12.42 \\
SL range $(\mathrm{cm})$ & $2.2-3.9$ & $4.0-10.9$ & $11-17.5$ & $11-19.5$ \\
\hline
\end{tabular}

community composition, and the other half was frozen $\left(-21^{\circ} \mathrm{C}\right)$ on board for biomass measurements.

We collected sardine juveniles (SL range: 4.0-11.0 $\mathrm{cm}$ ) and adults (SL range: 11-19.5 $\mathrm{cm}$ ) on both cruises and also collected late larvae (SL range: $2.2-4.0 \mathrm{~cm}$ ) in winter, as shown in Table 1 . The size at which individuals were considered adults $(11 \mathrm{~cm})$ was based on the observations by Tsagarakis et al. (2012) of the shift in schooling behaviour (at a size of $10.7 \mathrm{~cm}$ ), almost coinciding with the minimum landing size for sardine in the Mediterranean (11 cm, EC 1967/2006). To perform the daily ration analysis, consecutive hauls were performed during a 24-h cycle on each cruise, every three hours in PELMED07 and every four hours in JUVALION09. All specimens were caught with a pelagic trawling net equipped with a small-mesh codend (mesh length $5 \mathrm{~mm}$, ISO 1107) and towed at an average speed of 3.6 knots over a 30-40 min period. The samples were immediately frozen $\left(-21^{\circ} \mathrm{C}\right)$ after sorting on board by age groups.

\section{Anatomical analysis}

The following morphological measurements were performed: body wet weight (BW) in g and SL and total body length (TL) in mm. In all, 13 specimens of late larvae between 2.2 and $4.0 \mathrm{~cm} \mathrm{SL}, 56$ juveniles between 4.0 and $11.0 \mathrm{~cm} \mathrm{SL}$ and 67 adults between 11.0 and 19.5 $\mathrm{cm}$ SL were randomly selected from the two cruises to count the number of pyloric caeca and to measure the characteristics of the gill rakers according to the pro-

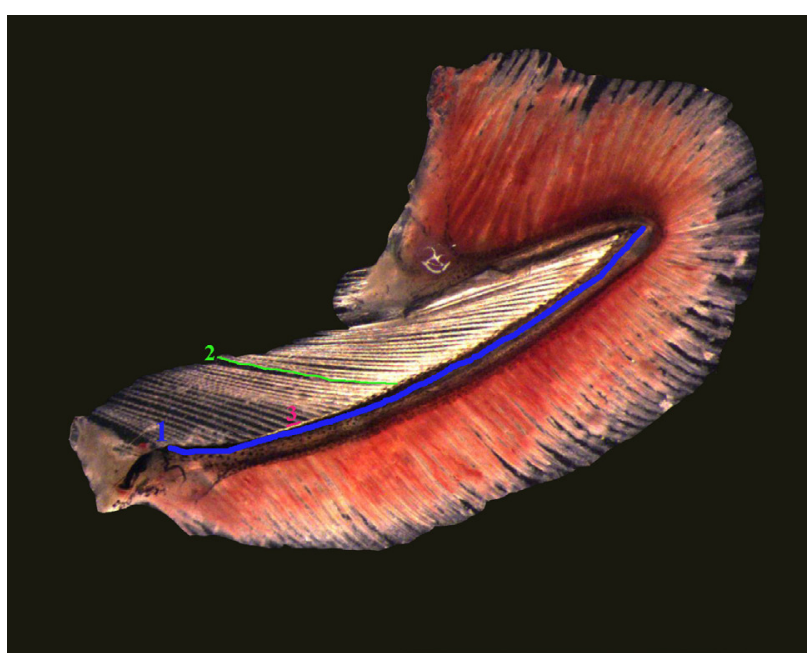

Fig. 2. - Photo of the first left branchial arch of a sardine adult, indicating how the different structures were measured: 1, length of ceratohypobranchial arch (blue line); 2 , length of a central gill raker (green line); 3 , space between two consecutive gill rakers, at their bases (pink line). cedures in Tanaka et al. (2006). In the first branchial arch (the lower or ceratohypobranchial branch) of the left side of the body (Fig. 2), the number of gill rakers was counted and the length of the ceratohypobranchial arch and the width of the gill raker spacings $\left(\mathrm{S}_{\mathrm{GR}}\right)$ in $\mathrm{mm}$ were measured. The $\mathrm{S}_{\mathrm{GR}}$ was averaged from five gill raker spacings on the basis of these rakers. Data on the number of pyloric caeca in specimens larger than $12 \mathrm{~cm} \mathrm{SL} \mathrm{were} \mathrm{not} \mathrm{presented.} \mathrm{The} \mathrm{measurements} \mathrm{were}$ made with Image J 1.4 software.

ANOVA was used to test the significance of the slopes of the regressions calculated for the anatomical variables.

\section{Daily ration analysis}

Up to 20 stomachs from each haul within the 24-h cycle in each season were dissected and the stomach contents carefully removed. Dissection was performed under a stereomicroscope, and the entire contents of each stomach were extracted individually in a Petri dish. The contents of the intestine were discarded to reduce bias caused by different rates of digestion and gut passage times or codend feeding (Hyslop 1980), and no regurgitation was detected. Particular care was used to separate the stomach epithelium from the prey items. The contents of each stomach were filtered on pre-dried, pre-weighed Whatman GF/C filters $(25 \mathrm{~mm}$ $\varnothing)$ and subsequently dried at $60^{\circ} \mathrm{C}$ for $48 \mathrm{~h}$. The dry weight (DW) of the stomach contents was measured to the nearest $0.1 \mathrm{mg}$.

The stomach fullness index (SFI) for each individual was calculated by dividing the DW of the stomach contents by the total fish wet weight (wet BW) according to the following equation:

$$
\mathrm{SFI}=(\mathrm{DW} / \text { wetBW }) 1000 \text {. }
$$

Daily ration estimates were obtained with two different models in which the mean SFI value from each tow was used:

a) the Elliott and Persson (1978) model, in which consumption over a given time interval $t$ is described by the equation

$$
C_{t}=\frac{R t\left(S_{t}-S_{0} e^{-R t}\right)}{1-e^{-R t}},
$$

where $C$ is consumption over time $t, S_{t}$ is the mean SFI over time $t, S_{0}$ is the mean SFI starting at time 0 and $R$ is the instantaneous gastric evacuation rate (Elliott and Persson 1978). The total consumption over an entire cycle $\left(C_{t}\right)$ is equal to the sum of the partial consumptions calculated for the $\mathrm{n}$ time intervals between tows over a complete cycle: 


$$
C_{t}=\sum_{1}^{n} C_{t n}
$$

b) the Eggers (1979) model, in which the consumption over a given time interval $t$ is described by the following equation:

$$
C_{t}-\left(S_{t}-S_{0}\right)=\bar{S} R t,
$$

where $C_{t}$ is the consumption over the feeding interval considered, $S_{t}$ is the mean SFI at the end of the interval, $S_{0}$ is the mean SFI at the beginning of the interval, $S$ is the mean SFI over the entire interval, $R$ is the instantaneous evacuation rate and $t$ is the duration of the interval.

For both models, the gut evacuation rate $(R)$ was calculated as described by the Elliott (1972) equation:

$$
S t=S_{0} e^{-R t}
$$

where $S_{t}$ is the mean SFI at time $t, S_{0}$ is the mean SFI at the beginning of the time interval and $R$ is the instantaneous evacuation rate.

A semi-logarithmic transformation of this equation was used to calculate $R$ for each consecutive pair of samples showing a decrease in the value of the mean SFI. The maximum $R$ value calculated was selected to represent the instantaneous gastric evacuation rate.

\section{Diet composition analysis}

In all, the stomachs of 334 late-larval, 145 juvenile and 268 adult sardine were dissected and opened under a stereomicroscope. As previously explained for the analysis of the diet, the contents of the intestine were discarded in this analysis, and no regurgitation was detected. Because no items were found in the esophagus, regurgitation due to sampling stress was considered absent. Only food items that could be identified were recorded (e.g. van der Lingen 2002). For juveniles and adults, pools of the contents of up to 20 stomachs for each tow, if available, were diluted to a known volume of filtered seawater as in van der Lingen (2002), and stomachs of late larvae were analysed individually. All the prey items were counted and identified up to the lowest possible taxonomic level.

A SIMPER analysis provided the average dissimilarity between seasons in the prey composition of both juveniles and adults. A one-way analysis of similarity (ANOSIM) was used to test the significance of the differences in the composition of the diet between seasons and size classes. The PRIMER software package (Version 6.1.9) (Clarke and Warwick 2001) was used to perform the SIMPER and ANOSIM analyses, grouping prey species categories based on Bray-Curtis mean similarities.

The contribution of each prey item to the diet was calculated with the index of relative importance (IRI, Pinkas et al. 1971) based on the following equation:

$$
\operatorname{IRI}=\left(\% W_{i}+\% N_{i}\right) \% F O_{i},
$$

where $W=$ dry weight of prey type $i$ in $\mu \mathrm{g}, N=$ number of individuals of prey $i$ in stomachs and $F O=$ frequency of occurrence of prey $i$ in stomachs. $W$ was obtained from estimates by Uye (1982), Saiz and Calbet (2007) and Borme et al. (2009).

Prey selectivity was estimated with Ivlev's diet selectivity index, E (Ivlev 1961) for each case analysed. The value of the index was calculated with the following equation:

$$
\mathrm{E}=\left(r_{i}-p_{i}\right) /\left(r_{i}+p_{i}\right)
$$

where $r_{i}$ is the proportion of prey item $i$ in the stomach and $p_{i}$ is the proportion of prey item $i$ available from the marine environment. The mesozooplankton and microplankton fractions in the samples were considered together, as total plankton, for the calculation of the Ivlev index.

The carbon content of each prey type, used for comparison with the numerical prey content, was estimated using equations and tables from Espinoza and Bertrand (2008) and Borme et al. (2009).

\section{Plankton analysis}

The qualitative analysis of plankton was performed in the laboratory. Individuals were identified to the lowest possible taxonomic level under the stereomicroscope (Wild M12, at 100× magnification). The mesozooplankton samples were analysed in aliquots representing approximately $10 \%$ of the sample and repeated until at least 400 copepods had been counted in each sample; additional subsamples were also taken for any other abundant organism (i.e. cladocerans during summer). Microplankton samples were subsampled differently: $1 \%$ to $2 \%$ of the original volume was analysed to estimate the presence of nauplii, dinoflagellates, ciliates and diatoms; small copepods (primarily copepodites) were analysed in volumes sufficient to count at least 400 individuals. Individuals of each identified taxon were counted and abundances (ind $\mathrm{m}^{-3}$ ) were calculated. The genera Clausocalanus, Ctenocalanus, Paracalanus and Parvocalanus were classified as the 'Clauso-Paracalanidae' group.

Differences between seasons in plankton biomass and abundance were evaluated with a nonparametric Kruskal-Wallis test at a significance level of $\mathrm{p}<0.05$.

\section{RESULTS}

\section{Development of trophic-related structures}

The means of all the morphological measurements are shown in Table 2.

Sardines of between 2.2 and $2.5 \mathrm{~cm} \mathrm{SL}$ already had approximately 10 short $(<5 \mathrm{~mm})$ gill rakers in the first branchial arch but no pyloric caeca. The number of gill rakers (GR) maintained a significantly positive trend $(p<0.05)$ with increasing size (Fig. $3 \mathrm{~A}$ ), but the slope of the GR/SL relationship was gentler in specimens larger than $5 \mathrm{~cm} \mathrm{SL}$. 
Table 2. - Means \pm Standard deviations of anatomical parameters of sardine.

\begin{tabular}{lccc}
\hline & Late larvae & Juveniles & Adults \\
\hline Standard length $(\mathrm{cm})$ & $3.15 \pm 0.58$ & $7.28 \pm 1.88$ & $13.61 \pm 0.99$ \\
Pyloric caeca & 0 & $90.39 \pm 34.93$ & $98.55 \pm 16.35$ \\
Gill rakers & $20.17 \pm 6.11$ & $43.15 \pm 9.43$ & $55.67 \pm 3.74$ \\
Arch length $(\mathrm{mm})$ & $2.68 \pm 1.10$ & $8.76 \pm 2.76$ & $18.87 \pm 3.25$ \\
Gill raker spacing $(\mathrm{mm})$ & $0.12 \pm 0.03$ & $0.20 \pm 0.02$ & $0.15 \pm 0.05$ \\
\hline
\end{tabular}

Pyloric caeca in sardines were first observed in specimens of $4 \mathrm{~cm}$ SL. After the pyloric caeca appeared, their number continued to increase significantly $(\mathrm{p}<0.05)$ until $12 \mathrm{~cm} \mathrm{SL}$, where their number reached a plateau between values of 120 and 140. Although the number of pyloric caeca after $12 \mathrm{~cm}$ SL remained within this range, we did not present these data because the counts of the exact number of caeca were extremely uncertain owing to the accumulation of fat around the caeca (Fig. 3B).

The mean length of the ceratohypobranchial arch was always positively correlated with the SL (Fig. 3C), ranging from approximately $1 \mathrm{~mm}$ in the smaller larvae to approximately $20 \mathrm{~mm}$ in larvae of $17 \mathrm{~cm}$ SL. The density of gill rakers $\left(\mathrm{D}_{\mathrm{GR}}\right.$; number of $\mathrm{GR} /$ length of branchial arch in $\mathrm{mm}$ ) showed a negative correlation with SL (Fig. 3D), varying from approximately 7.5 GR $\mathrm{mm}^{-1}$ branchial arch in the smallest larvae analysed to less than $4 \mathrm{GR} \mathrm{mm}^{-1}$ branchial arch in sardines of 17 cm SL.

\section{Daily ration and consumption rates}

A daily feeding pattern was observed for sardine juveniles in summer 2007 (Fig. 4A). The SFI values increased throughout the day, reaching a peak before sunset (sunrise time, 5:04 GMT; sunset time, 20:02 GMT). Subsequently, the SFI values decreased during the night. For sardine juveniles in summer 2007, the feeding period began at 5:12 GMT and ended at 16:56 GMT. During the same season, adults showed an increasing SFI from almost 0 at 8:00 until midnight (23:02), although the peak occurred at 11:07 (Fig. 4B).

In winter (sunrise time, 8:17 GMT; sunset time, 17:41 GMT), the juveniles had a feeding period of approximately 12 hours, from 4:34 to $16: 15$, when the SFI began to decrease (Fig. 4C). The adults did not show a clear pattern of feeding periodicity and appeared to feed continuously, although they had an especially low SFI after sunset (20:12) (Fig. 4D).

The evacuation and consumption rates of adults and juveniles in both seasons and calculated with both consumption models are shown in Table 3.
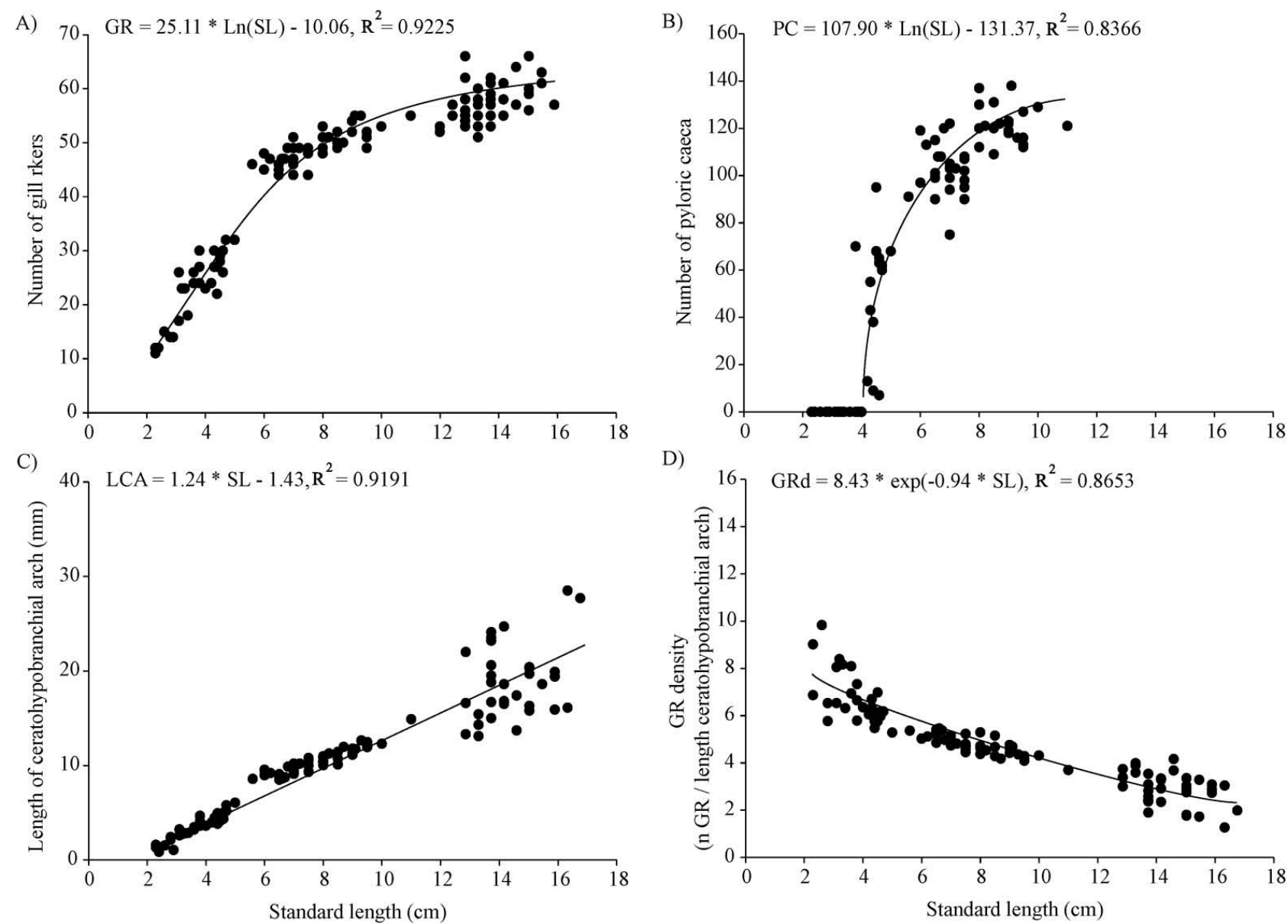

Fig. 3. - Relationships between standard length of sardine and different anatomical structures related to feeding. A, number of gill rakers GR; B, number of pyloric caeca PC; C, length of the ceratohypobranchial arch LCA (mm); D, density of gill rakers GRd (number of gill rakers / length of ceratohypobranchial arch). 

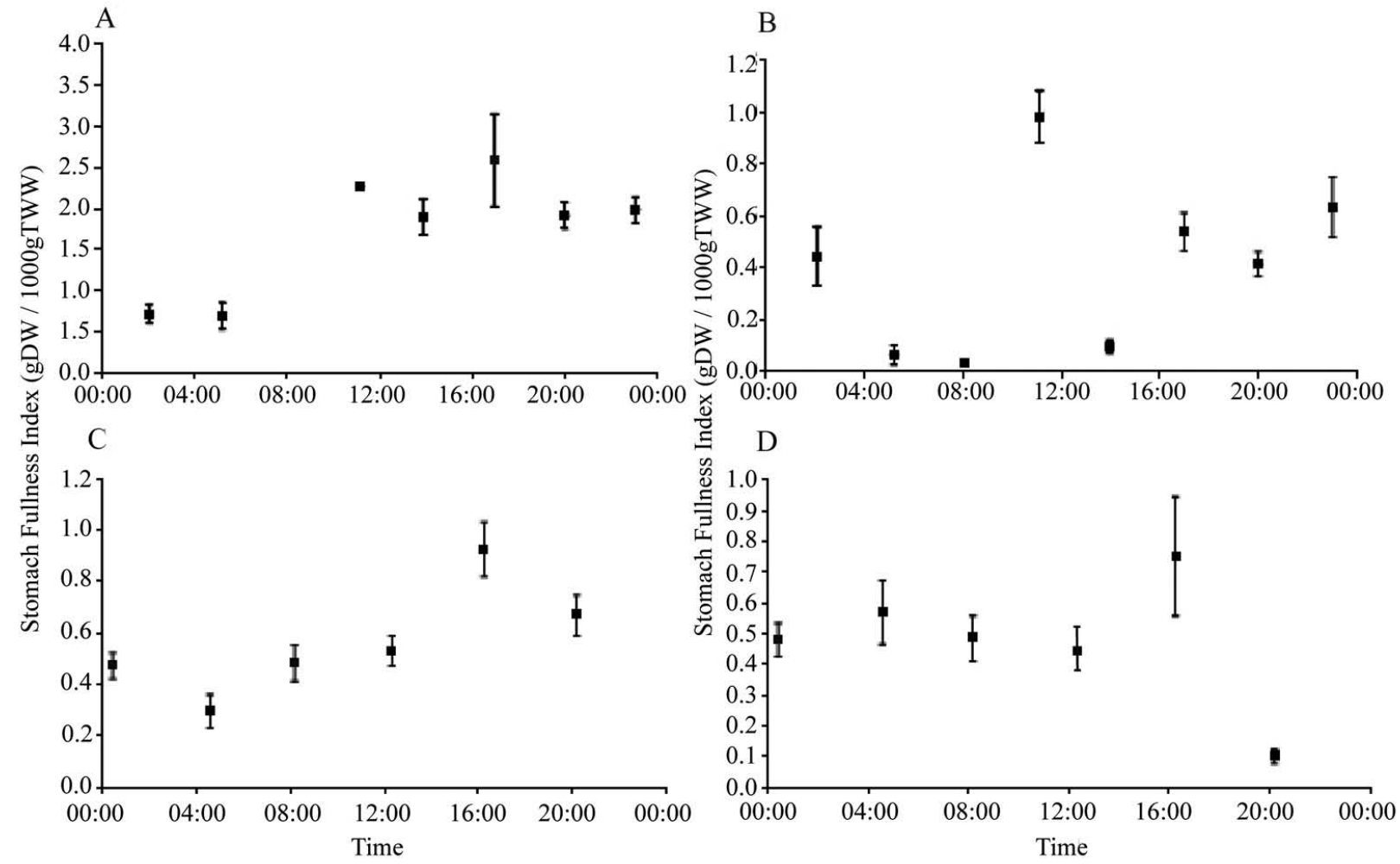

Fig. 4. - Mean stomach fullness index $\pm 95 \%$ CI plotted over time, as obtained in a sampling carried out in consecutive 24 hours. A, juveniles in summer; B, adults in summer; C, juveniles in winter; D, adults in winter. (Summer sunrise time, 5:04 GMT; summer sunset time, 20:02 GMT; winter sunrise time, 8:17 GMT; winter sunset time, 17:41 GMT).

\section{Diet composition}

Only 6 of the 334 stomachs of late larvae analysed contained prey, and only 2 of those prey items could be identified (Corycaeidae). For this reason, the diet of sardine late larvae is not presented in this study. Instead, we used the results from Costalago et al. (2012), based on isotopic signals, as indicative of the diet of sardine larvae.

Expressed as a percentage of the total number of prey, Cladocera dominated the stomachs of juveniles in summer $(84.30 \%)$ but occurred in only $60 \%$ of the stomachs analysed (Table 4). In winter, diatoms were the most abundant prey (72.26\%) and appeared in all the stomachs (Table 4). The stomachs of adult sardine in summer contained primarily Cladocera $(42.95 \%)$, Oncaea spp. (13.34\%) and other copepods (10.99\%), and all these prey types were found in all the stomachs (Table 3). In winter, diatoms and appendicularians were the most abundant prey types $(66.61 \%$ and $12.06 \%$, respectively) and the only prey types, together with other copepods, that were found in all the stomachs (Table 4).
The IRI values (Table 4) confirmed the importance of cladocerans in the diet of both size classes in summer and the importance of diatoms in the diet of sardine in winter. Additionally, other crustaceans (primarily decapod larvae) were present at low levels of numerical abundance in the stomachs but had a high IRI owing to their relatively high weight.

The SIMPER analysis of the numerical composition of the diet of juveniles showed that the average squared distance between seasons was $12.55 \%$. The prey items that contributed most heavily to this dissimilarity were Cladocera (21.47\%), decapod larvae (16.28\%), Temora spp. (11.38\%), Clauso-Paracalanidae (10.19\%) and $M$. rosea $(10.15 \%)$. In the SIMPER analysis based on the carbon composition of the prey, the average squared distance between seasons was $30.45 \%$, and the prey items that contributed most heavily to this result were decapod larvae (40.49\%), Cladocera (19.19\%) and unidentified copepods $(14.36 \%)$.

For adults, the SIMPER analysis based on the numerical composition of the prey showed an average squared distance between seasons of $7.61 \%$. The major contributor to that dissimilarity was phytoplankton

Table 3. - Estimates of gastric evacuation Rmax $\left(\mathrm{h}^{-1}\right)$ and consumption rates C (DW $1000 \mathrm{~g}^{-1}$ wet $\mathrm{BW}$ ) for sardine adults and juveniles in summer and winter. Consumption values are also expressed as percent total weight $(\% \mathrm{TW})$. DW, dry weight; $\mathrm{C}_{\mathrm{E}}$, daily ration according to the Eggers model; $\mathrm{C}_{\mathrm{E}-\mathrm{P}}$, daily ration according to the Elliott-Persson model.

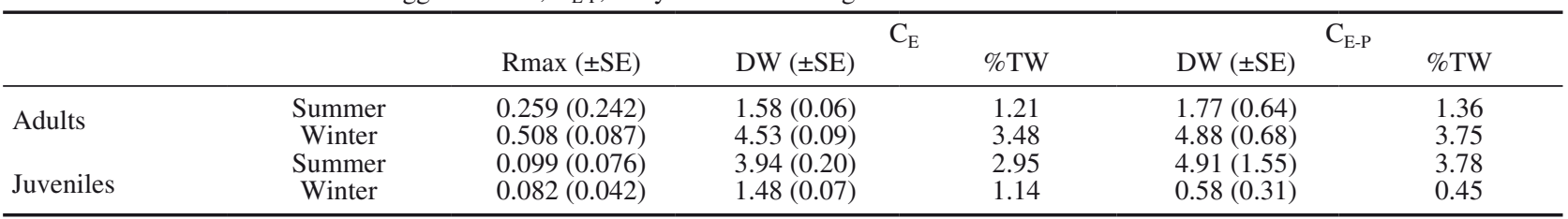


Table 4. - Total stomach contents by weight $(\mathrm{W})$, numerical abundance $(\mathrm{N})$ of prey, frequency of occurrence $(\mathrm{F})$ of prey in the stomachs and index of relative importance (IRI).

\begin{tabular}{|c|c|c|c|c|c|c|c|c|c|c|c|c|c|c|c|c|}
\hline & \multicolumn{8}{|c|}{ Juveniles } & \multicolumn{8}{|c|}{ Adults } \\
\hline & \multicolumn{4}{|c|}{ Summer } & \multicolumn{4}{|c|}{ Winter } & \multicolumn{4}{|c|}{ Summer } & \multicolumn{4}{|c|}{ Winter } \\
\hline & $\mathrm{W}(\%)$ & $\mathrm{N}(\%)$ & $\mathrm{F}(\%)$ & $\operatorname{IRI}(\%)$ & $\mathrm{W}(\%)$ & $\mathrm{N}(\%)$ & $\mathrm{F}(\%)$ & $\operatorname{IRI}(\%)$ & $\mathrm{W}(\%)$ & $\mathrm{N}(\%)$ & $\mathrm{F}(\%)$ & $\operatorname{IRI}(\%)$ & $\mathrm{W}(\%)$ & $\mathrm{N}(\%)$ & $\mathrm{F}(\%)$ & $\operatorname{IRI}(\%)$ \\
\hline Acartia spp. & 0.00 & 0.00 & 0 & 0.00 & 0.00 & 0.00 & 0 & 0.00 & 0.00 & 0.00 & 0 & 0.00 & 0.00 & 0.00 & 0 & 0.00 \\
\hline Appendicularia & 0.00 & 0.00 & 0 & 0.00 & 0.16 & 1.62 & 80 & 0.93 & 0.16 & 0.12 & 25 & 2.51 & 0.16 & 12.06 & 100 & 9.63 \\
\hline Calanus spp. & 0.00 & 0.00 & 0 & 0.00 & 0.00 & 0.00 & 0 & 0.00 & 0.00 & 0.00 & 0 & 0.00 & 0.00 & 0.00 & 0 & 0.00 \\
\hline Candacia spp. & 0.00 & 0.00 & 0 & 0.00 & 6.06 & 6.06 & 40 & 1.75 & 6.04 & 0.25 & 12.7 & 1.27 & 6.01 & 1.05 & 33.3 & 1.85 \\
\hline Centropages spp. & 0.00 & 0.00 & 0 & 0.00 & 0.21 & 0.21 & 20 & 0.06 & 0.00 & 0.00 & 0 & 0.00 & 0.21 & 0.17 & 16.7 & 0.05 \\
\hline Cladocerans & 1.21 & 84.30 & 60 & 51.47 & 0.00 & 0.00 & 0 & 0.00 & 1.13 & 42.95 & 100 & 14.29 & 1.12 & 5.42 & 16.7 & 0.86 \\
\hline Clauso-Paracalanidae & 0.32 & 1.02 & 40 & 0.54 & 0.30 & 0.30 & 80 & 1.83 & 0.30 & 2.62 & 62.5 & 6.51 & 0.30 & 0.17 & 16.7 & 0.06 \\
\hline Corycaeidae & 0.50 & 4.09 & 80 & 3.69 & 0.47 & 0.47 & 20 & 0.18 & 0.47 & 3.50 & 75 & 7.85 & 0.47 & 0.52 & 16.7 & 0.13 \\
\hline Diatoms & 0.00 & 0.00 & 0 & 0.00 & 0.00 & 0.00 & 100 & 47.75 & 0.00 & 8.24 & 75 & 8.32 & 0.22 & 66.61 & 100 & 52.65 \\
\hline Euterpina spp. & 0.00 & 0.00 & 0 & 0.00 & 0.12 & 0.12 & 20 & 0.08 & 0.01 & 4.37 & 62.5 & 6.69 & 0.00 & 0.00 & 0 & 0.00 \\
\hline Foraminiferans & 0.00 & 0.00 & 0 & 0.00 & 0.00 & 0.00 & 100 & 1.14 & 0.00 & 0.00 & 0 & 0.00 & 0.00 & 0.00 & 0 & 0.00 \\
\hline Microsetella rosea & 0.06 & 3.58 & 60 & 2.19 & 0.05 & 0.05 & 100 & 1.28 & 0.05 & 5.37 & 87.5 & 9.29 & 0.05 & 0.52 & 50 & 0.23 \\
\hline Molluscs & 0.00 & 0.00 & 0 & 0.00 & 0.22 & 0.22 & 20 & 0.04 & 0.22 & 1.50 & 50 & 5.15 & 0.00 & 0.69 & 33.3 & 0.18 \\
\hline Oithona spp. & 0.00 & 0.00 & 0 & 0.00 & 0.00 & 0.00 & 0 & 0.00 & 0.00 & 0.00 & 0 & 0.00 & 0.00 & 0.00 & 0 & 0.00 \\
\hline Oncaea spp. & 0.00 & 0.00 & 0 & 0.00 & 0.10 & 0.10 & 40 & 0.37 & 0.10 & 13.34 & 100 & 11.34 & 0.10 & 1.57 & 83.3 & 1.10 \\
\hline Other copepods & 3.64 & 1.02 & 40 & 1.87 & 3.46 & 3.46 & 100 & 9.26 & 3.45 & 10.99 & 100 & 11.10 & 3.43 & 8.74 & 100 & 9.58 \\
\hline Other crustaceans & 92.26 & 0.34 & 40 & 37.16 & 87.52 & 87.52 & 60 & 34.51 & 87.17 & 0.32 & 37.5 & 3.81 & 86.69 & 1.57 & 33.3 & 23.18 \\
\hline Polychaeta larvae & 0.00 & 0.00 & 0 & 0.00 & 0.34 & 0.34 & 20 & 0.06 & 0.00 & 0.00 & 0 & 0.00 & 0.34 & 0.17 & 16.7 & 0.07 \\
\hline Temora spp. & 0.93 & 1.36 & 40 & 0.92 & 0.88 & 0.88 & 20 & 0.12 & 0.88 & 2.37 & 50 & 5.24 & 0.87 & 0.69 & 33.3 & 0.41 \\
\hline Tintinnids & 0.00 & 0.00 & 0 & 0.00 & 0.07 & 0.07 & 40 & 0.60 & 0.00 & 0.00 & 0 & 0.00 & 0.00 & 0.00 & 0 & 0.00 \\
\hline
\end{tabular}

A)

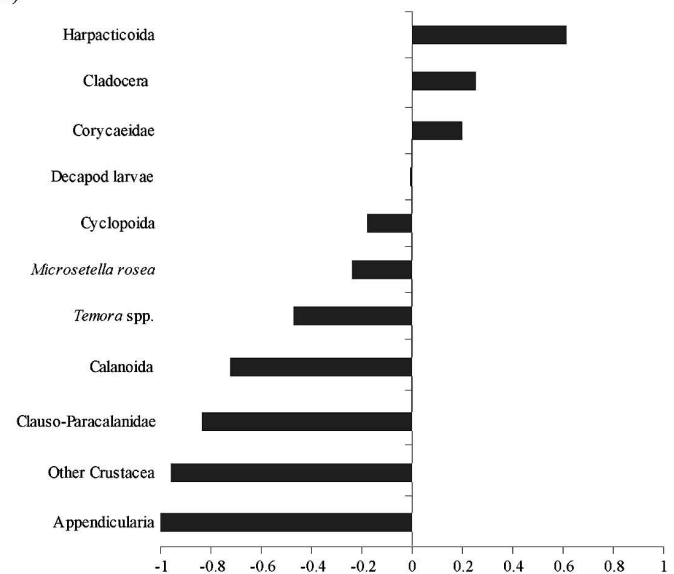

C)

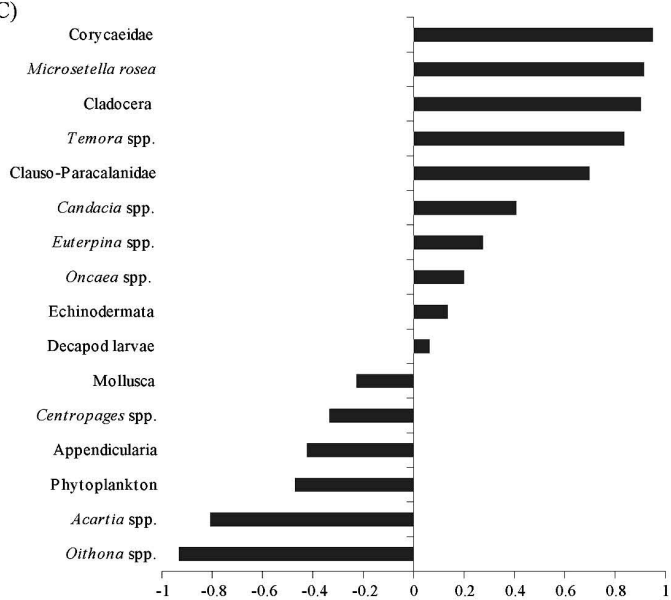

B)

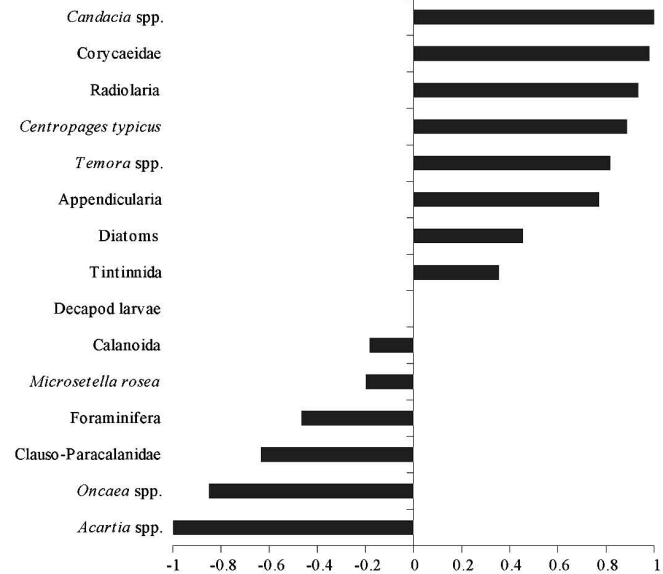

D)

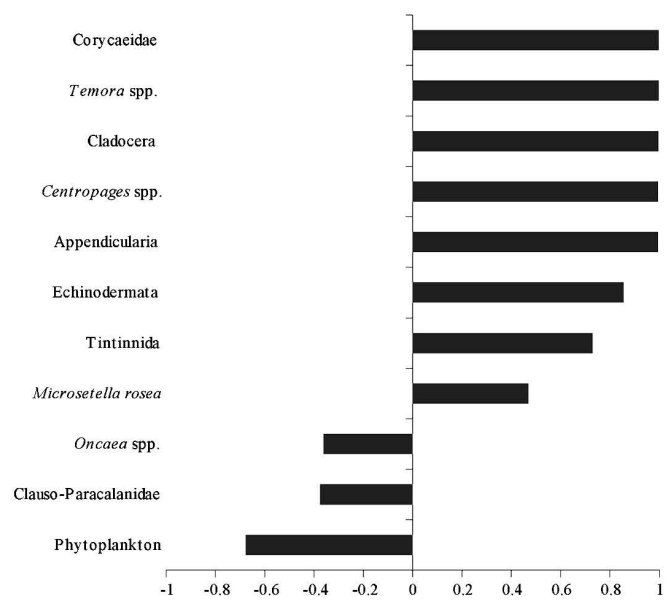

Fig. 5. - Ivlev's dietary index. A, sardine juveniles summer; B, sardine juveniles winter; C, sardine adults summer; D, sardine adults winter.

$(16.80 \%)$. In the SIMPER analysis of adult prey items based on carbon content, the average squared distance between seasons was $8.55 \%$. The prey items contributing most heavily to this dissimilarity were decapod larvae (47.14\%) and unidentified copepods (12.93\%).
According to the SIMPER analysis of the number of prey in summer, the average squared distance between the juvenile and adult diets was $12.99 \%$, owing primarily to Cladocera $(13.71 \%)$ and phytoplankton $(11.10 \%)$. In winter, the average squared distance 


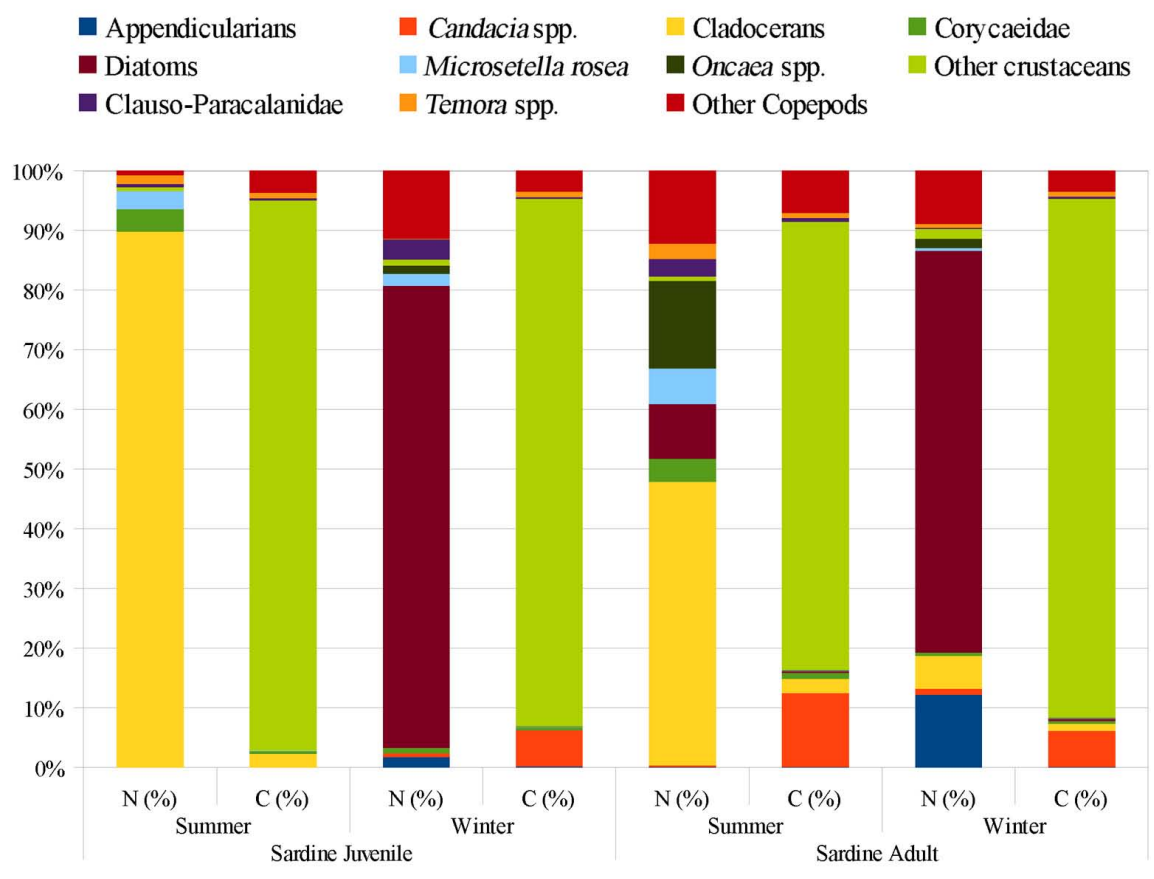

Fig. 6. - Stomach contents for the juveniles and adults of sardine in number $(\mathrm{N})$ and in carbon content $(\mathrm{C})$ of prey.

between size classes was $3.38 \%$, and the prey items contributing most heavily to this dissimilarity were tintinnids (18.88\%) and Clauso-Paracalanidae (11.13\%). In the SIMPER analysis of the carbon content of prey in summer, the average squared distance between the diets of juveniles and adults was $22.59 \%$ and was primarily due to decapod larvae $(40.34 \%)$, Cladocera $(15.30 \%)$ and unidentified copepods $(14.71 \%)$; in winter, the average squared distance between size classes was $4.73 \%$, and the main prey items explaining this dissimilarity were decapod larvae $(62.25 \%)$ and Candacia spp. (13.52\%).

An ANOSIM confirmed the significant differences in the composition of the diet between seasons (significance level of sample statistic: $0.001 \%$ and $0.01 \%$ for data based on the number of prey and the carbon fraction of the prey, respectively) and the significant differences between juveniles and adults $(0.3 \%$ and $0.008 \%$ for data based on the number of prey and the carbon fraction of the prey, respectively).

Ivlev's index of prey selectivity (Fig. 5) showed that the preferred prey items of sardine juveniles in summer were copepods, particularly Harpacticoidae, and cladocerans. In winter, Candacia spp., Corycaeidae and phytoplankton (radiolarians and diatoms) were the preferred prey items. Sardine adults in summer selected primarily Corycaeidae, Microsetella spp. and cladocerans. In winter, Corycaeidae, Temora spp. and Centropages spp., together with cladocerans and appendicularians, were the most positively selected prey types.

The proportion of carbon content of the prey showed the importance of the group 'other crustaceans' (composed primarily of decapod larvae) in both juvenile and adult sardine during the two seasons (Fig. 6). The data on the numerical percentage of prey types showed that cladocerans were more important in summer, diatoms in winter (Fig. 6).
Table 5. - Mean mesozooplankton and microplankton stock in terms of abundance and biomass during the two periods (Min, minimum; Max, maximum; SD, standard deviation).

\begin{tabular}{|c|c|c|c|}
\hline & & Summer & Winter \\
\hline \multicolumn{4}{|l|}{ Mesozooplankton } \\
\hline \multirow{4}{*}{$\begin{array}{l}\text { Total abundance } \\
\quad \text { (ind } \mathrm{m}^{-3} \text { ) }\end{array}$} & Min & 3767.1 & 1211.7 \\
\hline & Max & 11881.2 & 34522.3 \\
\hline & Mean & 8024.2 & 14559.7 \\
\hline & $\mathrm{SD}$ & 2484.3 & 12273.6 \\
\hline \multirow{4}{*}{$\begin{array}{l}\text { Biomass } \\
\left(\mathrm{mg} \mathrm{m}^{-3}\right)\end{array}$} & Min & 14.2 & 7.6 \\
\hline & $\operatorname{Max}$ & 54.6 & 484.1 \\
\hline & Mean & 33.6 & 53.2 \\
\hline & $\mathrm{SD}$ & 10.3 & 96.6 \\
\hline \multicolumn{4}{|l|}{ Microplankton } \\
\hline \multirow{3}{*}{$\begin{array}{l}\text { Total abundance } \\
\quad\left(\text { ind } \mathrm{m}^{-3} \text { ) }\right.\end{array}$} & Max & $\begin{array}{l}11180.0 \\
452339.3\end{array}$ & 487819.5 \\
\hline & Mean & 107734.7 & 299637.6 \\
\hline & $\mathrm{SD}$ & 138214.8 & 194726.2 \\
\hline \multirow{4}{*}{$\begin{array}{l}\text { Biomass } \\
\left(\mathrm{mg} \mathrm{m}^{-3}\right)\end{array}$} & Min & 9.1 & 7.8 \\
\hline & Max & 907.2 & 335.1 \\
\hline & Mean & 190.0 & 52.9 \\
\hline & $\mathrm{SD}$ & 277.5 & 72.6 \\
\hline
\end{tabular}

\section{Plankton composition}

Information on total microplankton and mesozooplankton abundance (ind $\mathrm{m}^{-3}$ ) and biomass $\left(\mathrm{mg} \mathrm{m}^{-3}\right)$ during the surveys is summarized in Table 5. The abundance and biomass of both mesozooplankton and microplankton were higher in winter except for the microplankton biomass, but no significant differences were found between the summer and winter abundances of either microplankton or mesozooplankton. Neither mesozooplankton nor microplankton biomass differed significantly between the two seasons.

The plankton was dominated by phytoplankton (primarily diatoms) and copepods during the two seasons $(52.8 \%$ and $30.1 \%$ in summer and $42.3 \%$ and $49.1 \%$ in winter for phytoplankton and copepods, respectively). The most abundant copepod species in 
summer were Paracalanus parvus (243602 ind $\mathrm{m}^{-3}$ ), Microsetella rosea (243622 ind $\left.\mathrm{m}^{-3}\right)$, Candacia $\mathrm{spp}$. (55326 ind $\left.\mathrm{m}^{-3}\right)$, Calocalanus spp. (55326 ind $\mathrm{m}^{-3}$ ) and Centropages typicus (17061 ind $\left.\mathrm{m}^{-3}\right)$. In winter, the most abundant copepod species were Ctenocalanus spp. (12353.57 ind $\left.\mathrm{m}^{-3}\right)$, Paracalanus spp. (12206.59 ind $\left.\mathrm{m}^{-3}\right)$, Labidobcera spp. (11139.83 ind $\left.\mathrm{m}^{-3}\right)$ and Oithona spp. (7717.51 ind $\left.\mathrm{m}^{-3}\right)$. Excluding copepods and phytoplankton, the planktonic group with the highest relative abundance in summer was cladocerans $(11.7 \%)$. In winter, similar percentages $(\sim 8.5 \%)$ of Mollusca, appendicularians and tintinnids were counted. Cnidaria, Doliolida, Echinodermata, Euphausiacea and Polychaeta also occurred in small percentages in both seasons $(<5 \%)$.

\section{DISCUSSION}

To depict how sardine in the Mediterranean Sea interact with the environment and to assess how prospective changes in the plankton community could affect sardine populations, an accurate description of the trophic dynamics of the species during all its life stages, from larvae to adults, is essential.

In this study, the stomach contents of sardine specimens were analysed to obtain information about the prey items consumed in summer and winter. Then, based on the study of the development of certain ontogenetic features, we also sought to determine the body size at which sardine have already developed a completely functional filtering mechanism and can begin to shift efficiently to a diet richer in phytoplankton.

We observed that pyloric caeca do not appear until metamorphosis begins (at approximately $4 \mathrm{~cm} \mathrm{SL}$ ). The subsequent development of the pyloric caeca is very rapid. No new pyloric caeca are formed after sardine reach approximately $8 \mathrm{~cm}$ SL. Although the existing pyloric caeca may continue growing in volume well after $8 \mathrm{~cm} \mathrm{SL}$, we can hypothesize that the digestive function of pyloric caeca (Buddington and Diamond 1986 ) is fully active as soon as sardine reach $8 \mathrm{~cm}$ SL.

Gill rakers appeared at an SL of $2.2 \mathrm{~cm}$ in our study. Similarly, in the studies of Lee (1961) and Andreu (1969), which thoroughly analysed the development of gill rakers in sardines from the western Mediterranean, a TL of $20 \mathrm{~mm}$ has been identified as the size at which gill rakers begin to grow in sardines. Van der Lingen et al. (2009), based on studies by Andreu (1969) and Garrido et al. (2007), presented information that can be compared with our results. Sardines from the Atlantic coast of the Iberian Peninsula seem to have more gill rakers than the sardines analysed for this study in the Mediterranean. This is a very interesting finding that may indicate that there are also important differences in the diet of these two separate populations that led their morphology to evolve in divergent ways and should be further investigated. Van der Lingen et al. (2009) also showed that sardines in the northeastern Atlantic, from Vigo, NW Spain, had an apparently significant higher number of gill rakers than anchovies of the same size in that region. How these two similar species differ in their feeding patterns in different environments, such as the Atlantic versus the Mediterranean, is another matter that needs to be researched in depth.

We also found that the increasing trend in the number of gill rakers becomes much less pronounced when sardines reach $7 \mathrm{~cm}$ SL. This result means that filter feeding on small particles (according to Garrido et al. (2007), <750 $\mu \mathrm{m}$ is the prey size threshold for filter feeding) can be totally effective beginning at that body size. This result is also consistent with the results of Nikolioudakis et al. (2012) on sardine in the Aegean Sea and with the results of Scofield (1934), who studied Sardinops sagax in California and stated that sardines with a TL of 70-100 $\mathrm{mm}$ are able to filter diatoms.

We observed that the length of the ceratohypobranchial arch increases linearly with SL. Moreover, because the number of gill rakers on this arch becomes stable at a certain SL, the gap between gill rakers would also increase with SL. This result might mean that the ability to filter feed on the smallest particles would be reduced, but we believe that the denticles could help to compensate for the loss in filtering capacity resulting from the wider inter-raker gaps (King and Macleod 1976).

The information obtained from a complete analysis of the daily ration can also be useful to validate the ongoing development of bioenergetic models for small pelagic fish species (Urtizberea et al. 2008). Because at least two full 24-h cycles with sampling every $3 \mathrm{~h}$ or less are needed for a confident assessment of the diel variation in feeding intensities (Tudela and Palomera 1995), we cannot guarantee that the pattern described here represents the normal behaviour of sardines in the northwestern Mediterranean. Nevertheless, the results of our analysis coincide with those of previous studies that performed a more comprehensive analysis of the daily ration. For example, we observed a general pattern of diurnal feeding activity that extends until dusk, as observed also by Andreu (1969) in the Atlantic and Nikolioudakis et al. (2011) in the Aegean Sea. In addition, though the ElliottPersson model is claimed to be appropriate only if the frequency of sampling is every three hours or less (Elliott and Persson 1978), we found no differences between the alternative models that we evaluated. Moreover, we found no clear patterns of differences in consumption rates between sizes and seasons, although higher rates are normally expected in summer (Nikolioudakis et al. 2011). However, we found that evacuation rates were always higher in adults than in juveniles. This result may mean that larger individuals have higher metabolic rates, but this is also expected because instantaneous evacuation rates are affected by fish size (Elliott and Persson 1978).

Nevertheless, high evacuation rates in sardine adults could make sense if larger sardines $(7 \mathrm{~cm} \mathrm{SL}$ and higher) use filter feeding rather than particulate feeding, as we demonstrated here, owing to the higher energetic requirements imposed by continuous swimming activity relative to the energy requirements of smaller individuals or similar species (e.g., anchovy), whose typical locomotor pattern consists of a glide following a tail beat (Lasker 1970). 
Studies of the diet of European sardine on the southern coast of England (Lebour 1921) and in Turkish waters (Demirhindi 1961) have reported contrasting results. Lebour (1921) stated that sardine shift after metamorphosis to a diet with a higher proportion of phytoplankton, whereas Demirhindi (1961) claimed that the diet consisted almost entirely of zooplankton at all ages. This discrepancy appears to have been resolved by the present study and by other recent studies. Based on observations of the high relative importance of prey $<750 \mu \mathrm{m}$ in the diet, Bode et al. (2004) and Garrido et al. (2007), in Atlantic waters, and Nikolioudakis et al. (2012), in the eastern Mediterranean, have suggested that filter feeding is the principal feeding behaviour of adult sardines in the wild. The findings of the present study in the western Mediterranean that sardines above $7 \mathrm{~cm}$ SL can efficiently feed on phytoplankton confirm the results of the other recent studies cited above. In fact, sardines above $4 \mathrm{~cm}$ SL in the western Mediterranean were eating primarily diatoms and decapod larvae in winter, exhibiting their ability to perform both filter feeding and particulate feeding. However, sardine larvae in this region, according to Morote et al. (2010) and to Costalago et al. (2012), generally ate copepods and did not appear to be able to feed on phytoplankton. This absence of phytoplankton feeding is most likely due to a lack of the specific body structures needed to filter small particles.

Bulgakova (1996) explained that anchovy Engraulis encrasicolus could shift between filter feeding and particulate feeding depending on the concentrations of different prey items. Our results imply that such shifts could also be the case in sardine. Other authors (Bode et al. 2004 and Garrido et al. 2007) have stated that larger prey, such as copepods and decapod larvae, can also be an important component of sardine stomach contents, particularly if the abundance of other prey items is relatively low. This observation suggests that particulate feeding might also be used in the wild to compensate for periods of low food availability (Margalef 1960). Similarly, we observed that in winter, when the abundances of both micro- and mesozooplankton were higher, both juvenile and adult sardines relied more, in terms of numerical abundance, on diatoms than on any other prey type. In summer, however, both juveniles and adults fed heavily on cladocerans. The selection of cladocerans rather than copepods in summer may result from the greater ability of copepods to avoid capture by fish (Strickler et al. 2005).

Although this study and others (Morote et al. 2010, Costalago et al. 2012) have shown that sardine larvae are obligate particulate feeders whose basic prey is copepods, juvenile and adult sardine are opportunistic feeders and show a more heterogeneous diet than similar species (e.g., anchovy) (Tudela and Palomera 1997, Costalago et al. 2012). In addition, several authors have found correspondences between the plankton in the environment and in the stomachs (Varela et al. 1990, Bode et al. 2003), suggesting that sardine are essentially non-selective filter-feeders and that their diets reflect the ambient plankton composition.
Comparisons of the numerical composition of prey in the stomachs of sardine and anchovy suggest that the juveniles of these two species show no interspecific dietary overlap and that interspecific dietary overlap is also most likely absent in the adults (Costalago et al. 2014). However, the larvae of both species might share the same alimentary resources if sea surface temperatures continue to increase (Costalago et al. 2011). Moreover, other species that have not generally been common in the Gulf of Lions but have increased in recent years, such as Sardinella aurita (Sabatés et al. 2006) and Sprattus sprattus (GFCM 2012, D. Roos, personal communication), are potentially intraguild competitors with sardine (Palomera et al. 2007, Morote et al. 2008) and could place further pressure on its population.

In addition, although cannibalism has not been reported in S. pilchardus in the Mediterranean, it is probable that intraspecific diet overlap occurs between juveniles and adults, as confirmed by the similar feeding patterns observed here in all sardine individuals larger than $7 \mathrm{~cm}$ SL. Because this factor can naturally control population growth, it should be considered in proposals for plans to manage the resource.

The analysis of stomach contents is a classical and widely used technique for studying the ecology of fish (Hynes 1950, Hyslop 1980, Wootton 1999). The numerical composition of the prey items in fish stomachs provides information about the diet of the fish and can be highly useful in comparing similar species of predators (van der Lingen and Hutchings 1998, Costalago et al. 2014). However, numerical analysis of the prey items in the stomachs of clupeid species can overestimate the contribution made by phytoplankton because of the small size and low carbon:volume ratio of phytoplankton relative to those of zooplankton. For this reason, the assessment of the stomach contents of planktophagous fish is more informative if the methods used are based on the carbon fraction of ingested prey, as is the case for several recent studies (van der Lingen 2002, Garrido et al. 2008, Borme et al. 2009) and for the present study. We have compared the results of both methods (carbon and numerical contents) and shown that differences between the two analytical techniques exist for adult sardine. In the analyses based on carbon content, for example, the largest prey types (decapod larvae and copepods) contributed more to the seasonal differences in the diet than any other prey type regardless of their numerical importance. However, the use of numerical percentages indicated that phytoplanktonic prey items were the most important. Similarly, we found that dietary differences between juveniles and adults in both summer and winter based on carbon content were due to decapod larvae and large copepods and were due to cladocerans in summer. However, the analyses based on the numerical composition of prey items in the stomachs indicated that those differences were due primarily to small copepods (Clauso-Paracalanidae) and phytoplankton and were also due to cladocerans in summer. We have observed that in juveniles, the prey types that best described the diet (Cladocera, decapod 
larvae and copepods) were almost the same according to both methods for measuring stomach contents. We hypothesize that the reason for this finding is that juveniles did not prey on phytoplankton during summer but generally fed on cladocerans, whereas adults in summer showed diatoms in $75 \%$ of the stomachs, representing $8.24 \%$ of the total number of prey items. These numbers would increase the importance of diatoms in the adult diet relative to their role in the diet of juveniles.

The composition of the diet based on the percentage by number of prey types differed from the composition based on the percentage by weight. The numerical percentage gave more importance to cladocerans and diatoms in summer and winter, respectively, but the weight percentage was much higher for decapod larvae than for any other prey type in both seasons. However, the IRI tended to give more importance to the numerically more dominant prey rather than to those with higher weights. In addition, the results of the SIMPER analysis showed greater mean distances for the diet composition based on carbon content.

We compared our results, based on stomach contents, to those of Costalago et al. (2012), which were based on stable isotope analysis and therefore provided a longer-term view of the diet prior to capture. The isotope analysis indicated that appendicularians were always the most important prey for both juveniles and adults in both summer and winter, except that juveniles in summer consumed primarily cladocerans. In contrast, the current study found that appendicularians were among the most important prey types only in terms of the IRI in adults in winter. This difference demonstrates that certain prey that are more easily digested, such as appendicularians, can often be underestimated by analyses of fish stomach contents (Capitanio et al. 2005).

The results based on the Ivlev selectivity index showed that the prey types most positively selected by juveniles and adults (and also by larvae, according to Costalago et al. (2012)), in addition to cladocerans in summer, were small copepods, such as Corycaeidae and Harpacticoidae (primarily Microsetella spp.), in summer and winter. This result is of particular interest in view of the importance of this type of copepod in the pelagic food web (Turner 2004). These copepods represent a link through small pelagic fishes that connects bacterial plankton with ecologically and economically important species that prey on small pelagic fishes (de Laender et al. 2010).

Molinero et al. (2005) showed that high positive anomalies in water temperature in the northwestern Mediterranean can cause a decrease in the population of copepods. An obvious effect of such a decrease on the trophic dynamics of sardine in the region is that sardine would be forced to rely more heavily on primary producers as food. In addition, Conversi et al. (2009) claimed that species of small copepods would most likely increase as a result of the anticipated warming of the Mediterranean Sea. This increase would impose additional limits on the expansion of phytoplankton species. Given the energetic advantage of filtering for a well-adapted filter-feeding species such as sardine (van der Lingen et al. 2006), the limited availability of small food particles could have negative consequences for sardine populations. Moreover, the expected future decrease in the cold period in the Mediterranean could limit the spawning season of sardine (Coll et al. 2008a) and could cause competition between sardine larvae and anchovy larvae (Costalago et al. 2011).

Sardine populations support a large community of species at higher trophic levels. Several of these species are commercially important (Coll et al. 2006, Preciado et al. 2008, Banaru et al. 2012). Conservation of sardine and the suitable management of its fishery in the Gulf of Lions are therefore required to guarantee both socio-economic and ecological stability in the region. This study demonstrates that, in addition to the effects of fisheries on sardine populations (Coll et al. 2008b), these populations can also be strongly affected by changes in the planktonic community.

\section{ACKNOWLEDGEMENTS}

The authors gratefully acknowledge the collaboration of Ignacio Álvarez-Calleja and Marta Albo for their highly valuable work on the plankton analysis and the morphological parameter analysis, respectively, and of B. Liorzou, J.L. Bigot, D. Ross L. Buttay, B. Moli and all the crew of the N/O L'Europe for their help during the cruises. This work was conducted under the European project SARDONE (FP6 - 44294). D.C. was funded from 2007 to 2010 with a PhD contract by the SARDONE project. ECOTRANS project (CTM201126333 ) contributed to the final edition of the paper.

\section{REFERENCES}

Andreu B. 1969. Las branquispinas en la caracterización de las poblaciones de Sardina pilchardus (Walb.). Invest. Pesq. 33: 425-607.

Bakun A., Agostini V.N. 2001: Seasonal patterns of wind-induced upwelling/downwelling in the Mediterranean Sea. Sci. Mar. 65: 243-257.http://dx.doi.org/10.3989/scimar.2001.65n3243

Banaru D., Mellon-Duval C., Roos D., Bigot J.L., Souplet A., Jadaud A., Beaubrun P., Fromentin, J.M. 2013. Trophic structure and fisheries interactions in the Gulf of Lions (north-western Mediterranean). J. Mar. Sys. 111-112: 45-68. http://dx.doi.org/10.1016/j.jmarsys.2012.09.010

Barange M., Bernal M., Cercole M.C., Cubillos L., Cunningham C.L., Daskalov G.M., de Oliveira J.A.A., Dickey-Collas M., Hill K., Jacobson L., Køster F.W., Masse J., Nishida H., Ñiquen M., Oozeki Y., Palomera I., Saccardo S.A., Santojanni A., Serra R., Somarakis S., Stratoudakis Y., van der Lingen C.D., Uriarte A., Yatsu A., 2009. Current trends in the assessment and management of stocks. In: Checkley D., Roy C., Oozeki Y., Alheit J. (eds), Climate Change and Small Pelagic Fish Stocks. Cambridge University Press, pp. 191-255.

Beaugrand G., Brander, K. M., Lindley J.A., Souissi S., Reid P.C. 2003. Plankton effect on cod recruitment in the North Sea. Nature 426: 661-664. http://dx.doi.org/10 .1038/nature02164

Blaxter J.H.S., Hunter J.R. 1982. The biology of the clupeoid fishes. Adv.Mar. Biol. 20: 1-223. Academic Press, New York. http://dx.doi.org/10.1016/S0065-2881(08)60140-6

Bode A., Carrera P., Lens S. 2003. The pelagic foodweb in the upwelling ecosystem of Galicia (NW Spain) during spring: natural abundance of stable carbon and nitrogen isotopes. ICES J. Mar. Sci. 60: 11-22. http://dx.doi.org/10.1006/jmsc.2002.1326

Bode A., Álvarez-Ossorio M.T., Carrera P., Lorenzo J. 2004. Reconstruction of the trophic pathways between plankton and the North Iberia sardine (Sardina pilchardus) using stable isotopes. Sci. Mar. 68: 165-178. 
http://dx.doi.org/10.3989/scimar.2004.68n1165

Borme D., Tirelli V., Brandt S., Fonda S., Arneri E. 2009. Diet of Engraulis encrasicolus in the northern Adriatic Sea (Mediterranean): ontogenetic changes and feeding selectivity. Mar. Ecol. Prog. Ser. 392: 193-200. http://dx.doi.org/10.3354/meps08214

Borme D., Tirelli V., Palomera I. 2013. Feeding habits of European pilchard late larvae in a nursery area in the Adriatic Sea. J. Sea Res. 78: 8-17. http://dx.doi.org/10.1016/j.seares.2012.12.010

Buddington R.K., Diamond J.M. 1986. Aristotle revisited: The function of pyloric caeca in fish. Proc. Natl. Acad. Sci. USA 83: 8012-8014. http://dx.doi.org/10.1073/pnas.83.20.8012

Bulgakova Y. 1996. Feeding in the Black Sea anchovy: diet composition, feeding behaviour, feeding periodicity and daily rations. Sci. Mar. 60(2): 283-284.

Capitanio B.F., Pájaro M., Esnal G.B. 2005. Appendicularians: an important food supply for the Argentine anchovy Engraulis anchoita in coastal waters. J. Appl. Ichthyol. 21: 414-419. http://dx.doi.org/10.1111/j.1439-0426.2005.00657.x

Checkley D., Alheit J., Oozeki Y., Roy C. 2009. Climate change and small pelagic fish. Cambridge University Press, Cambridge, $392 \mathrm{pp}$.

Clarke K.R., Warwick R.M. 2001. Change in marine communities: an approach to statistical analysis and interpretation, 2nd edition. PRIMER-E, Plymouth, 172 pp.

Coll M., Palomera I., Tudela S., Sarda F. 2006. Trophic flows, ecosystem structure and fishing impacts in the South Catalan Sea, northwestern Mediterranean. J. Mar. Syst. 59: 63-96. http://dx.doi.org/10.1016/j.jmarsys.2005.09.001

Coll M., Palomera I., Tudela S., Dowd M. 2008a. Food-web dynamics in the South Catalan Sea ecosystem (NW Mediterranean) for 1978-2003. Ecol. Model. 217: 95-116. http://dx.doi.org/10.1016/j.ecolmodel.2008.06.013

Coll M., Libralato S., Tudela S., Palomera I., Pranovi F. 2008b. Ecosystem overfishing in the ocean. PLoS One 3(12): e3881. http://dx.doi.org/10.1371/journal.pone.0003881

Conversi A, Peluso T and Fonda-Umani S. 2009. Gulf of Trieste: A changing ecosystem. J. Geophys. Res. 114

Conway D.V.P., Coombs S.H., Fernandez de Puelles M.L., Tranter P.R.G. 1994. Feeding of larval sardine, Sardina pilchardus (Walbaum), off the north coast of Spain. Bol. Inst. Esp. Oceanogr. 10: 165-175.

Costalago D., Tecchio S., Palomera I., Álvarez-Calleja I., OspinaÁlvarez A., Raicevich S. 2011. Ecological understanding for fishery management: condition and growth of anchovy late larvae during different seasons in the northwestern Mediterranean. Estuar. Coast. Shelf Sci. 93: 350-358. http://dx.doi.org/10.1016/j.ecss.2011.05.005

Costalago D., Navarro J., Álvarez-Calleja I., Palomera I. 2012. Ontogenetic and seasonal changes in the feeding habits and trophic levels of two small pelagic fish species. Mar. Ecol. Prog. Ser. 460: $169-181$. http://dx.doi.org/10.3354/meps09751

Costalago D., Palomera I., Tirelli V. 2014. Seasonal comparison of the diets of European anchovy Engraulis encrasicolus and sardine Sardina pilchardus juveniles in the Gulf of Lions. J. Sea Res. http://dx.doi.org/10.1016/j.seares.2014.02.008

Cushing D.H. 1990. Plankton production and year-class strength in fish populations: an update of the match/mismatch hypothesis. In: Blaxter, J.H.S., Southward, A.J. (eds), Adv. Mar. Biol. Academic Press Limited, San Diego, CA, pp. 250-313.

de Laender F., Van Oevelen D., Soetaert K., Middelburg J.J. 2010. Carbon transfer in herbivore- and microbial loop-dominated pelagic food webs in the southern Barents Sea during spring and summer. Mar. Ecol. Prog. Ser. 398: 93-107. http://dx.doi.org/10.3354/meps08335

Demirhindi U. 1961. Nutrition of the sardine (Sardina pilchardus Walb.). P. Techn. Papers GFCM 6: 253-259.

Durbin A.G. 1979. Food selection by plankton feeding fishes. In Clepper H. (ed.) Predator-prey systems in fisheries management. Sport Fishing Institute. Washington DC, pp. 203-218.

Eggers D.M. 1979. Comments on some recent methods for estimating food consumption by fish. J. Fish. Res. B. Canada 36: 1018-1019.

Elliott J.M. 1972. Rates of gastric evacuation in brown trout, Salmo tnitta. L. Freshwat. Biol. 2: 1-18. http://dx.doi.org/10.1111/j.1365-2427.1972.tb01575.x

Elliott J.M., Persson L. 1978. The estimation of daily rates of food consumption for fish. J. Anim. Ecol. 47: 977-991. http://dx.doi.org/10.2307/3682

Espinoza P., Bertrand, A. 2008. Revisiting Peruvian anchovy (En- graulis ringens) trophodynamics provides a new vision of the Humboldt Current system. Prog. Oceanogr. 79: 215-227. http://dx.doi.org/10.1016/j.pocean.2008.10.022

Estrada M. 1996. Primary production in the northwestern Mediterranean. In: Palomera I., Rubiés, P. (eds), The European anchovy and its environment. Sci. Mar. 60(2): 55-64.

Forget P., André G. 2007. Can satellite-derived chlorophyll imagery be used to trace surface dynamics in coastal zone? A case study in the northwestern Mediterranean Sea. Sensors 7: 884-904. http://dx.doi.org/10.3390/s7060884

Frederiksen M., Edwards M., Richardson A.J., Halliday N.C., Wanless S. 2006. From plankton to top predators: bottom-up control of a marine food web across four trophic levels. J. Anim. Ecol. 75: $1259-1268$. http://dx.doi.org/10.1111/j.1365-2656.2006.01148.x

Fu C., Gaichas S., Link J.S., Bundy A., Boldt J.L., Cook A.M., Gamble R., Utne K.R., Liu H., Friedland K.D. 2012. Relative importance of fisheries, trophodynamic and environmental drivers in a series of marine ecosystems. Mar. Ecol. Prog. Ser. 459: 169-184. http://dx.doi.org/10.3354/meps09805

Garrido S., Marçalo A., Zwolinski J., van der Lingen C.D. 2007. Laboratory investigations on the effect of prey size and concentration on the feeding behaviour of Sardina pilchardus. Mar. Ecol. Prog. Ser. 330: 189-199. http://dx.doi.org/10.3354/meps330189

Garrido S., Ben-Hamadou R., Oliveira P.B., Cunha M.E., Chícharo M.A., van der Lingen C.D. 2008. Diet and feeding intensity of sardine Sardina pilchardus: correlation with satellite-derived chlorophyll data. Mar. Ecol. Prog. Ser. 354: 245-256. http://dx.doi.org/10.3354/meps07201

Gerking S. 1994. Feeding ecology of fish. Academic Press, San Diego. US. 416 pp.

General Fisheries Commission for the Mediterranean 2012, Working Group on Stock Assessment of Small Pelagic Species. Meeting Report, Split, Croacia.

Giannoulaki M.M.P., Liorzou B., Leonori I., Valavanis V.D., Tsagarakis K., Bigot L.J., Roos D., de Felice A., Campanella F., Somarakis S., Arneri E., Machias A. 2011. Habitat suitability modelling for sardine juveniles (Sardina pilchardus) in the Mediterranean Sea. Fish. Oceanogr. 20: 367-382. http://dx.doi.org/10.1111/j.1365-2419.2011.00590.x

Giannoulaki M., Iglesias M., Tugores M.P., Bonnano A., Patti B., De Felice A., Leonori, I., Bigot, J.L., Tičina, V., Pyrounaki, M.M., Tsagarakis, K., Machias, A., Somarakis, S., Schismenou E., Quinci E., Basilone G., Cuttita A., Campanella F., Miquel J., Oñate D., Roos D., Valavanis V. 2013. Characterising the potential habitat of European anchovy Engraulis encrasicolus in the Mediterranean Sea, at different life stages. Fish. Oceanogr. 22(2): 69-89. http://dx.doi.org/10.1111/fog.12005

Hynes H.B.N. 1950. The food of freshwater sticklebacks (Gasterosteus aculeatus and Pygosteus pungitius) with a review of methods used in studies of the food of fishes. J. An. Ecol. 19: 36-58. http://dx.doi.org/10.2307/1570

Hyslop E.J. 1980. Stomach contents analysis- a review of methods and their application. J. Fish Biol. 17: 411-429. http://dx.doi.org/10.1111/j.1095-8649.1980.tb02775.x

Ivlev V.S. 1961. Experimental ecology of the feeding of fishes. Yale University Press, New Haven. 302 pp.

James A.G. 1986. Are clupeid microphagists herbivorous or omnivorous? A review of the diets of some commercially important clupeids. S. Afr. J. Mar. Sci. 7: 61-177.

King D.P.F., Macleod P.R. 1976. Comparison of the food and the filtering mechanism of pilchard Sardinops ocellata and anchovy Engraulis capensis off South West Africa. Invest. Rep. Sea Fish. Br. S. Afr. 111: 1-22.

Lasker R. 1970. Utilization of zooplankton energy by a Pacific sardine population in the California current. In: Steele, J.H. (ed) Marine Food Chains. Oliver and Boyd, Edinburgh, pp. 265-284.

Lebour M.V. 1921. The food of young clupeoids. J. Mar. Biol. Ass. UK 12(3): 458-467.

Lee J.Y. 1961. La sardine du golfe du lion (Sardina pilchardus sardina Regan). Rev. Trav. Inst. Pêch. Mar. 25(4) : 418-513.

Lleonart J., Maynou F. 2003. Fish stock assessments in the Mediterranean: state of the art. Sci. Mar. 67(Suppl. 1): 37-49. http://dx.doi.org/10.3989/scimar.2003.67s137

Lloret J., Palomera I., Salat J., Sole I. 2004. Impact of freshwater input and wind on landings of anchovy (Engraulis encrasicolus) and sardine (Sardina pilchardus) in shelf waters surrounding the Ebre (Ebro) River delta (north-western Mediterranean). Fish. Oceanogr. 13: 102-110. 
http://dx.doi.org/10.1046/j.1365-2419.2003.00279.x

Margalef R. 1960. Fluctuations in abundance and availability cause by biotic factors. Proceedings of the World Scientific Meeting on biology of sardines and related species, FAO 3: 1265-1285.

Massuti M., Oliver M. 1948. Estudio de la biometría y biología de la sardina de Mahón (Baleares), especialmente de su alimentación. Bol. Instit. Esp. Oceanogr. 3: 1-15.

Molinero J.C., Ibanez F., Nival P., Buecher E., Souissi S. 2005. The North Atlantic Climate and northwestern Mediterranean plankton variability. Limnol. Oceanogr. 50: 1213-1220. http://dx.doi.org/10.4319/lo.2005.50.4.1213

Morote E., Olivar M.P., Villate F., Uriarte I. 2008. Diet of round sardinella, Sardinella aurita, larvae in relation to plankton availability in the NW Mediterranean. J. Plank. Res. 30(7): 807-816. http://dx.doi.org/10.1093/plankt/fbn039

Morote E., Olivar M.P., Villate F., Uriarte I. 2010. A comparison of anchovy (Engraulis encrasicolus) and sardine (Sardina pilchardus) larvae feeding in the Northwest Mediterranean: influence of prey availability and ontogeny. ICES J. Mar. Sci. 67: 897-908. http://dx.doi.org/10.1093/icesjms/fsp302

Motoda S. 1959. Devices of simple plankton apparatus. Mem. Fac. Fish. Hokkaido Univ. 7: 73-94.

Munuera I., González-Quirós R. 2006. Analysis of feeding of Sardina pilchardus (Walbaum, 1792) larval stages in the central Cantabrian Sea. Sci. Mar. 70S1: 131-139. http://dx.doi.org/10.3989/scimar.2006.70s1131

Nikolioudakis N., Palomera I., Machias A., Somarakis S. 2011. Diel feeding intensity and daily ration of the sardine Sardina pilchardus. Mar. Ecol. Prog. Ser. 437: 215-228. http://dx.doi.org/10.3354/meps09275

Nikolioudakis N., Isari S., Pitta P., Somarakis S. 2012. Diet of sardine Sardina pilchardus: and 'end-to-end' field study. Mar. Ecol. Prog. Ser. 453: 173-188. http://dx.doi.org/10.3354/meps09656

Palomera I., Olivar M.P., Salat J., Sabates A., Coll M., Garcia A., Morales-Nin B. 2007. Small pelagic fish in the NW Mediterranean Sea: an ecological review. Progr. Oceanogr. 74: 377-396 http://dx.doi.org/10.1016/j.pocean.2007.04.012

Pinkas L., Oliphant M.S., Iverson I.L.K. 1971. Food habits of albacore, bluefin tuna, and bonito in California waters. Calif. Dep. Fish Game Fish. Bul. 152: 1-105.

Preciado I., Velasco F., Olaso I. 2008. The role of pelagic fish as forage for the demersal fish community in the southern Bay of Biscay. J. Mar. Syst. 72: 407-417. http://dx.doi.org/10.1016/j.jmarsys.2007.04.007

Rasoanarivo R., Folack J, Champalbert G., Becker B, 1991. Relations entre les communautés phytoplanctoniques et l'alimentation de Sardina pilchardus Walb. dans de golfe de Fos (Méditerrané occidentale): influence de la lumière sur l'activité alimentaire des larves. J. Exp. Mar. Biol. Ecol. 151: 83-92. http://dx.doi.org/10.1016/0022-0981(91)90017-Q

Sabatés A., Martín P., Lloret J., Raya V. 2006. Sea warming and fish distribution: the case of the small pelagic fish, Sardinella aurita, in the western Mediterranean. Global Change Biol. 12(11): 2209 2219. http://dx.doi.org/10.1111/j.1365-2486.2006.01246.x

Saiz E., Calbet A. 2007. Scaling of feeding in marine calanoid copepods. Limnol. Oceanogr. 52(2): 668-675. http://dx.doi.org/10.4319/1o.2007.52.2.0668

Salat J. 1996. Review of hydrographic environmental factors that may influence anchovy habitats in northwestern Mediterranean. In: Palomera I., Rubiés, P. (eds), The European anchovy and its environment. Sci. Mar. 60, 21-32.

Scofield E.C. 1934. Early life history of the California sardina (Sardina caerulea) with special reference to the distribution of the eggs and larvae. Cal. Div. Fish Game Fish. Bull. 41: 1-49.

Strickler J.R., Udvadia A.J., Marino J., Radabaugh N., Ziarek J., Nihongi A. 2005. Visibility as a factor in the copepod-planktivorous fish relationship. Sci. Mar. 69(Suppl. 1): 111-124. http://dx.doi.org/10.3989/scimar.2005.69s 1111
Tanaka H., Aoki I., Ohshimo S. 2006. Feeding habits and gill raker morphology of three planktivorous pelagic fish species off the coast of northern and western Kyushu in summer. J. Fish Biol. 68: 1041-1061. http://dx.doi.org/10.1111/j.0022-1112.2006.00988x

Tsagarakis K., Pyrounaki M.M., Giannoulaki M., Somarakis S., Machias A. 2012. Ontogenetic shift in the schooling behaviour of sardines, Sardina pilchardus. An. Behav. 84: 437-443. http://dx.doi.org/10.1016/j.anbehav.2012.05.018

Tudela S., Palomera I. 1995. Diel feeding intensity and daily ration in the anchovy Engraulis encrasicolus in the northwest Mediterranean Sea during the spawning period. Mar. Ecol. Prog. Ser. 129: 55-61. http://dx.doi.org/10.3354/meps129055

Tudela S., Palomera I. 1997. Trophic ecology of European anchovy Engraulis encrasicolus in the Catalan Sea (Northwest Mediterranean). Mar. Ecol. Prog. Ser. 160, 121-134. http://dx.doi.org/10.3354/meps160121

Turingan R.G., Beck J.L., Krebs J.M., Licamele J.D. 2005. Development of feeding mechanisms in marine fish larvae and the swimming behavior of zooplankton prey: implications for rearing marine fishes. In: Lee C.S., O’Bryen P.J., Marcus N.M. (eds), Copepods in Aquaculture. Blackwell Publishing Professional, Ames, IA, USA, pp. 119-132 http://dx.doi.org/10.1002/9780470277522.ch10

Turner J.T. 2004. The importance of small planktonic copepods and their roles in pelagic marine food webs. Zoo. Stud. 43(2): 255-266.

Urtizberea A., Fiksen O., Folkvord A., Irigoien X. 2008. Modelling growth of larval anchovies including diel feeding patterns, temperature and body size. J. Plank. Res. 30(12): 1369-1383. http://dx.doi.org/10.1093/plankt/fbn090

Uye S 1982. Length-weight relationships of important zooplankton from the Inland Sea of Japan. J. Oceanog. Soc. Japan 38: 149158. http://dx.doi.org/10.1007/BF02110286

van der Lingen C.D. 1994. Effect of particle size and concentration on the feeding behaviour of adult pilchard Sardinops sagax. Mar. Ecol. Prog. Ser. 109: 1-13. http://dx.doi.org/10.3354/meps 109001

van der Lingen C.D. 2002. Diet of sardine Sardinops sagax in the southern Benguela upwelling ecosystem. Afr. J. Mar. Sci. 24: 301-316.

van der Lingen C.D., Hutchings L. 1998. Comparative trophodynamics of sardine Sardinops sagax and anchovy Engraulis capensis in the southern Benguela. Afr. J. Trop. Hydrobiol. Fish. 8: 11-18. http://dx.doi.org/10.4314/ajthf.v8i1.1384

van der Lingen C.D., Hutchings L., Field J.G. 2006. Comparative trophodynamics of anchovy Engraulis encrasicolus and sardine Sardinops sagax in the southern Benguela: are species alternations between small pelagic fish trophodynamically mediated? Afr. J. Mar. Sci. 29(3 and 4): 465-477.

van der Lingen C.D., Bertrand A., Bode A., Brodeur R., Cubillos L., Espinoza P., Friedland K., Garrido S., Irigoien X., Möllman C., Rodriguez-Sanchez R., Tanaka H., Temming A. 2009. Trophic dynamics. In: Checkley D.M., Roy C., Alheit J., Oozeki Y. (eds), Climate change and small pelagic fish. GLOBEC Project Office, Plymouth (UK): 112-157.

Varela M., Alvarez-Ossorio M.T., Valdes L. 1990. Metodo para el estudio cuantitativo del contenido estomacal de la sardina. Resultados preliminares. Bol. Ins. Esp. Oceanogr. 6: 117-126.

Voulgaridou P., Stergiou K.I. 2003. Trends in various biological parameters of the European sardine, Sardina pilchardus (Walbaum, 1792), in the Eastern Mediterranean Sea. Sci. Mar. 67(Suppl. 1): 269-280. http://dx.doi.org/10.3989/scimar.2003.67s1269

Wainwright P.C., Richard B.A. 1995. Predicting patterns of prey use from morphology of fishes. Env. Biol. Fish. 44: 97-113. http://dx.doi.org/10.1007/BF00005909

Wootton R.J. 1999. Ecology of Teleost Fishes. 2nd Edition. Springer, New York, 386 pp. 